\title{
CHANGES IN THE USE OF NATURAL RESOURCES AND HUMAN IMPACT IN THE KARST ENVIRONMENT OF THE VENETIAN PREALPS (ITALY)
}

\author{
SPREMEMBE V IZKORIŠČANJU NARAVNIH VIROV \\ IN VPLIV ČLOVEKA NA KRAŠKO OKOLJE V BENEŠKIH \\ PREDALPAH (ITALIJA)
}

\author{
Ugo SAURO $^{1}$
}

\begin{abstract}
UDC 504.5:551.44(234.3)

Ugo Sauro: Changes in the Use of Natural Resources and $\mathrm{Hu}$ man Impact in the Karst Environments of the Venetian Prealps

In the Venetian Prealps the old model of resources use was for many aspects of sustainable type, in equilibrium with the natural dynamics. Episodes of strong impact occurred only in some particular areas and in specific economical and political situations. After the Second World War dramatic changes in the resources management have taken place, induced by the urban and industrial development. The traditional system of self-sustained economy has completely collapsed and has been replaced by an open economy more dependent on that of the large urban sprawl of the plain. Such development is clearly incompatible with the local environmental dynamics and it is difficult to be modified, because it triggers self-sustaining processes. The problem to individuate new more compatible directions for the development is, for a large part, a cultural problem and it may not be solved without a cultural revolution. Local people must be helped to understand the karst geo-ecosystem, the natural realm, the landscape, the local history, and the cultural heritage. Starting from such knowledge, local people have to develop a strong sense of belonging to their own geographical units and to become and to feel protagonists, responsible of their own development, capable to lead it.
\end{abstract}

Keywords: human impact, karst, and sustainable development, Venetian Prealps, Italy.

Izvleček

UDK 504.5:551.44(234.3)

Ugo Sauro: Spremembe vizkoriščanju naravnih virov in vpliv človeka na kraško okolje v Beneških Predalpah

Nekdanji način izkoriščanja virov v Beneških Predalpah je bil s številnih vidikov sonaraven, $\mathrm{v}$ ravnotežju $\mathrm{z}$ naravnimi spremembami. Močan vpliv na okolje je bil le občasen, le na nekaterih območjih in $\mathrm{v}$ posebnih gospodarskih in političnih razmerah. Po 2. svetovni vojni so se zaradi urbanizacije in industrializacije zgodile dramatične spremembe $\mathrm{v}$ upravljanju $\mathrm{z}$ viri. Že od nekdaj utečeni način samozadostnega gospodarstva se je v celoti zrušil in zamenjalo ga je odprto gospodarstvo, bolj odvisno od hitrega širjenja mest v ravnini. Tak razvoj nikakor ni združljiv s krajevno dinamiko okolja in ga je težko spremeniti, saj sproži razvoj, ki poteka dalje sam od sebe. Težko je izdvojiti bolj sprejemljive smeri razvoja, saj gre pretežno za vprašanje kulture in teh težav ni mogoče rešiti brez »kulturne revolucije«. Krajevnemu prebivalstvu je treba pomagati, da bodo razumeli kraške geosisteme, naravne danosti, pokrajino, krajevno zgodovino, kulturno dediščino. Pričenši s takim znanjem naj bi krajevno prebivalstvo razvilo močan čut pripadnosti svoji geografski enoti in naj bi postalo in se čutilo odgovorno in sposobno za svoj lastni razvoj.

Ključne besede: vpliv človeka, kras, sonaravni razvoj, Beneške Predalpe, Italija.

\footnotetext{
${ }^{1}$ Dipartimento di Geografia dell'Università di Padova, Via del Santo 26, IT - 35123 Padova, Italia; e-mail: ugo.sauro@unipd.it Received / Prejeto: 06.09.2006
} 


\section{INTRODUCTION}

During the past centuries, nearly until the Second World War, in most of the pre-alpine environments man managed the resources trending to equilibrium with the natural dynamics. In other words, the local human communities were engaged to apply methods of sustainable development. Actually, there was not a real development in the sense of a change of the conditions of life but a kind of steady status. The price to pay not to alter such equilibrium was the emigration of the surplus of the human population.
After the Second World War dramatic changes in the natural resources use have taken place in the karst environments of the Venetian Prealps resulting from the open economy more dependent on that of the large diffuse city of the plain (Sauro, 1977, 1987; 1993; 1994, 1999a; 1999b; 2003; Sauro et al., 1991, 1995).

To develop a strategy for a future development, conserving, as possible, an ecological balance with the natural processes it is important to consider the different models of resources use applied in the past and the present day situation.

\section{THE OLD MODEL OF SUSTAINABLE TYPE}

A good example of application of a model of this type is represented by the small mountain settlements of Monti Lessini called "contrade", with their surrounding countryside. A "contrada" was a settlement of patriarchal type, a kind of collective farm made up by a few houses and some rustic buildings: the "teda" type, a combination of a cowshed and a hayloft, the pigsty, the hen-house and others collective structures such as the bread oven and the "baito" (a dairy farm managed by the inhabitants of several nearby "contrade").

The inhabitants of each "contrada" owned the surrounding land consisting both of forested plots for wood and charcoal production, and of meadow plots for hay production and cattle or sheep grazing. Minor plots, often near to the houses, were used for agriculture and garden-culture to produce vegetables. The meadow areas were utilized also for fruit trees growing.

The big problem of the absence or scarcity of surface water was solved collecting for the human use the rainfall and snow melting water of the roofs of the buildings, mostly made up by large stone slabs, by conveying it to underground tanks consisting in cylindrical recipes built up with stone walls and clay, called "possi". Surface water was collected for the livestock, inside closed depressions in the meadows realized by the excavation and damming of dry valleys, waterproofed with clay, called "posse".

Each family owned a few cattle, exactly the number that could be sustained by the production of the pertinent meadow area. The production of cheese and butter was managed corporately. During the year, there was a turnover in the management of the "baito". Each member managed the "baito" during periods distributed in all the seasons working the milk produced by all, for a whole quantity corresponding to its own total evaluated yearly production.

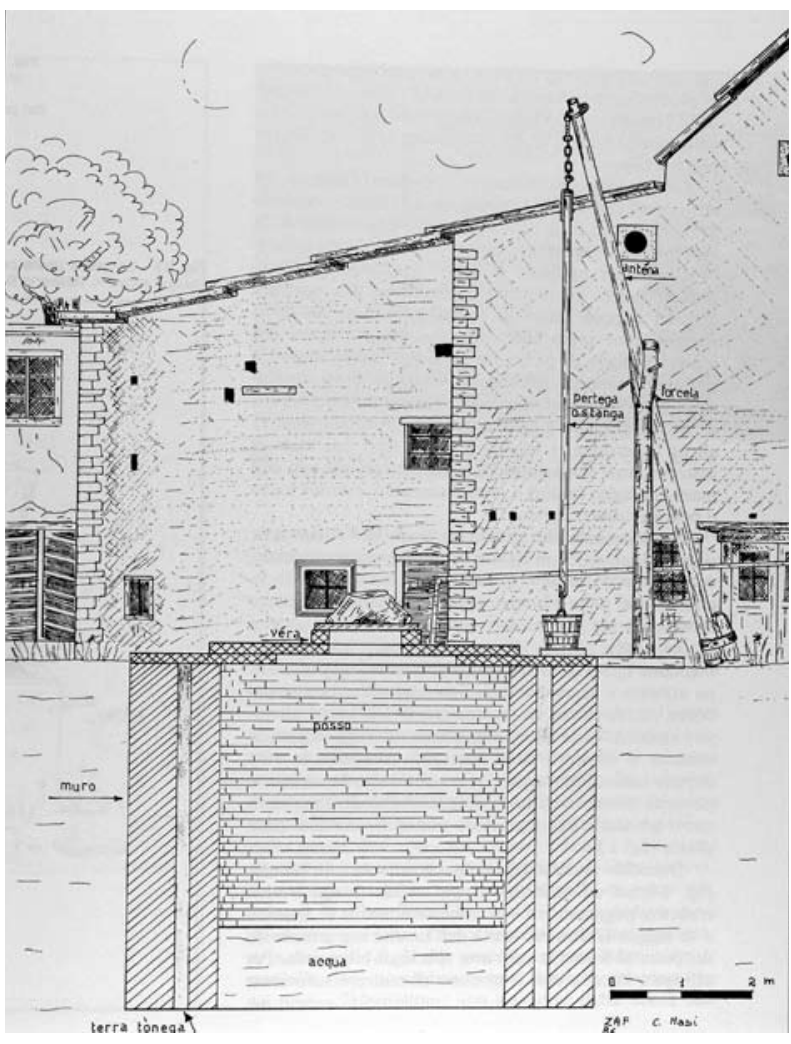

Fig. 1: Sketch of the old system of storing the rainwater of the roofs of the buildings inside cisterns (called "possi") build with stones and waterproofed with clayey soil sediments.

(drawing of Ferdinando Zanini in Avesani et al., 1986)

The butter and cheese were partly sold to get the money necessary to buy products like flour, polenta and wine, and obviously others goods like clothes, etc. But usually the circulating money was really few. 


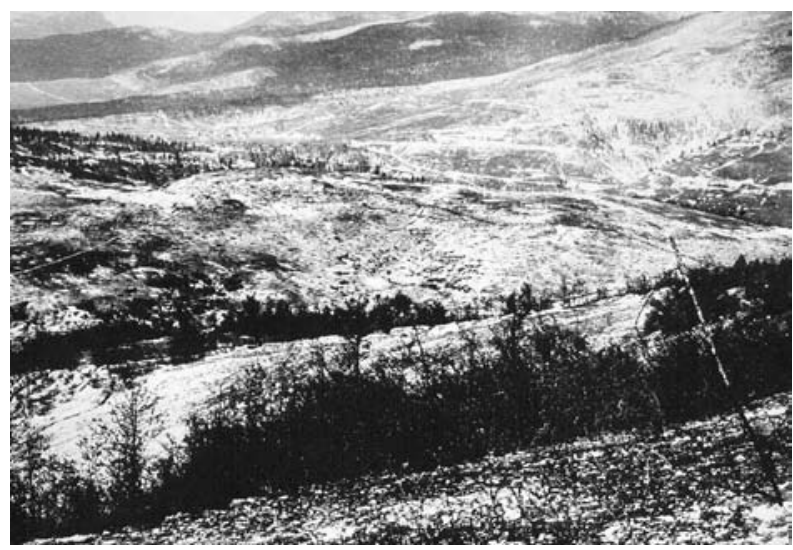

Integrative activities were the production and commerce of charcoal, wood, stone, lime, ice, flints for guns, different types of handicrafts, etc.

In general, the economy was of a self-sufficient type and the impact of man on the environment was very limited: the inhabitants were careful not to alter the delicate equilibrium of the different environments such as the forest, the meadow and the pasture.

Fig. 2: The stony desert created by the bombing of the Sette Comuni Plateau during the First World War.

The white stone fragments created by the explosions are scattered and appear as a snow cover.

\section{SOME “OLD” CASES OF STRONG HUMAN IMPACT}

Cases of strong impact are localized and linked with specific economical and political situations.

A significant example is represented by the history of land use of the upper part of the Sette Comuni Plateau, a pasture area of common property of the local inhabitants. When the Sette Comuni Plateau became part of the Republic of Venice in 1404, the special low of "pensionatico" was established to favour the mountain population as a compensation of the duty to control the state boundary. The shepherds of the plateau were allowed to bring the flocks in the plain in the period between October and March (six months of the year), also entering in the private fields. This privilege caused an increase of the flocks' consistency and a surcharge of the summer pastures. In the $18^{\text {th }}$ Century the sheep number reached nearly 200.000 heads corresponding to a density in the mountain area during the summer grazing period of about $500 / \mathrm{km}^{2}$. The impact on the soil of the pasture was very strong and caused a desertification and a regression of the sheep rearing.

Other episodes of strong impact in some areas are represented by the battles of the First World War. The Piccole Dolomiti, Sette Comuni and Monte Grappa massifs became major battlegrounds of the Italian and Austrian armies. Thousands of kilometres of trenches, tunnels, roads and railways were hastily built. There were large artillery battles. At some times on Sette Comuni Plateau 1500 guns were firing more than 200 tonnes of projectiles each day. Ten of thousands of craters were created by the explosions. In some photographs taken after bombing entire hills made up by a chalk type limestone looked like snowfields because of the rocky fragments.

\section{THE RECENT EVOLUTON}

Very rapid changes in the resources management have taken place after the Second World War, according with the new economic styles promoted by the urban and industrial development.

The changes occurring in the last 50 years are relatively complex. Schematising the phenomenon it is possible to note:

- a decrease of population in the mountain areas caused by a rural exodus, affecting especially the minor settlements; most of these and in particular those farthest from the towns and the villages have been abandoned or are utilized only seasonally as second houses or as structures for the agriculture;
- a strong decrease of the percent of population involved in farming activities;

- an increase of the percent of population involved in other activities (services, industry, tourism, etc.);

- a progressive abandonment of the land use of many plots and a corresponding expansion of the forested areas;

- a simplification of the agricultural landscape, with disappearance of some types of land use (a kind of desharpening and homogenisation of the traditional landscape);

- in some areas, the development of systems of large specialized farms, as poultry farms, pig farms, cattle 
farms; the poultry farms are located especially in the hilly and low mountain belt, the cattle farms in the middle mountain belt;

- the urbanisation of some of the most valuable mountain areas, caused by the explosion of the mass tourism and in particular by the development of the "vacation homes"; beside the "second houses", many others building and structures have developed as resort hotels, markets, sports grounds, ski complexes, roads, parking areas, etc;

- the building of complexes of ski plants as ski lifts and chair lifts, and the creation of large ski-tracks obtained by the excavation and the movements of large masses of rocks;

- the opening of large industrial quarries of limestone utilized as ornamental stone (Bondesan \& Meneghel, 1991).

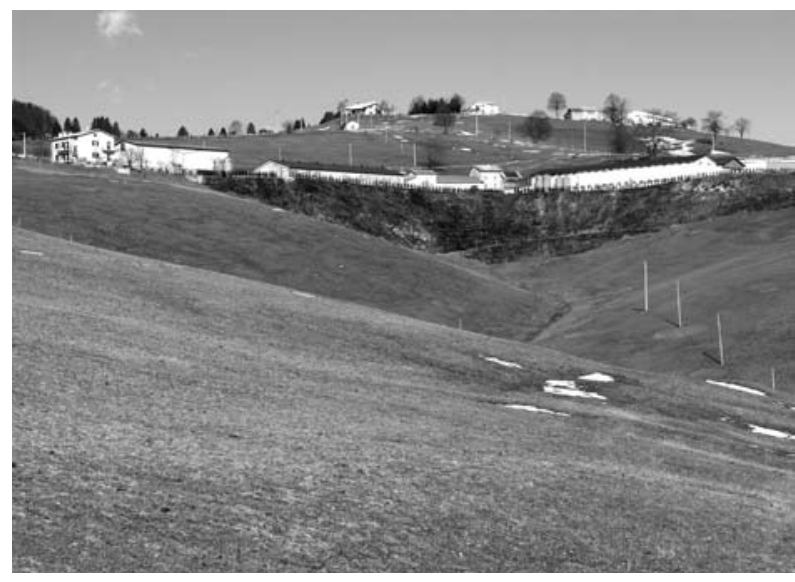

Fig. 3: Large cowsheds of a modern cattle farm of the Monti Lessini near Bosco Chiesanuova. The old contrada is hidden behind the large hangar-like buildings (centre of the photo).

According with these changes, the traditional system of self-sustained economy has completely collapsed and has been replaced by a more open economy integrated with that of the large diffuse city of the plain. This is evident, considering that most of the fodder to breed the cattle and the pigs, and of the poultry-feed are imported in the mountain area from outside. So a much larger bio-

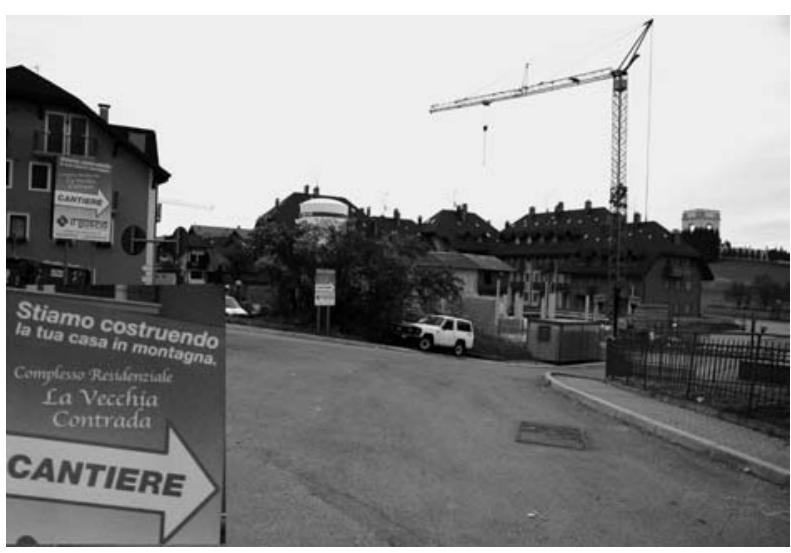

Fig. 4: New vacation housing in Asiago (Sette Comuni Plateau). In the sign-board (enlarged in the foreground left) the new complex is presented as "La Vecchia Contrada", that is the old type of settlement called contrada (in the reality it is very different).

mass is involved in the environmental system. A large quantity of liquid wastes is dispersed and contributes to the modification of the soils and to the pollution of the surface and underground waters.

During the summer and winter seasons in the urbanized areas of the mountains there is an impressive increase of the human population and a corresponding increase of the liquid and solid waste production. The sewages are partly lost in the environment and drained into creeks and sinkholes. In the last 30 years the nitrate content of the base level waters has more than doubled. Most of the water circulating in the aqueducts is pumped from the base level springs or the alluvial aquifers of the valleys and of the plain.

It is obvious that such development is incompatible with the local environmental dynamic. Also the economic system is less stable than the old one. For instance, the oscillations of the prices of some products like the milk, a product that may be imported from the less developed countries of East Europe, may cause the breakdown of the breeding and dairy farms; recently there has also been a period of collapse of the price of the chicken meat caused by the psychosis of the bird-flu.

\section{THE NECESSITY OF A CULTURAL REVOLUTION}

The big challenge of the present time is to individuate a strategy capable to modify the local economic mechanisms, governing them towards better and, if possible, sustainable development models. This is not a simple task, also because some phenomena, like the urbanisation, the quarrying, etc have started positive feedback 


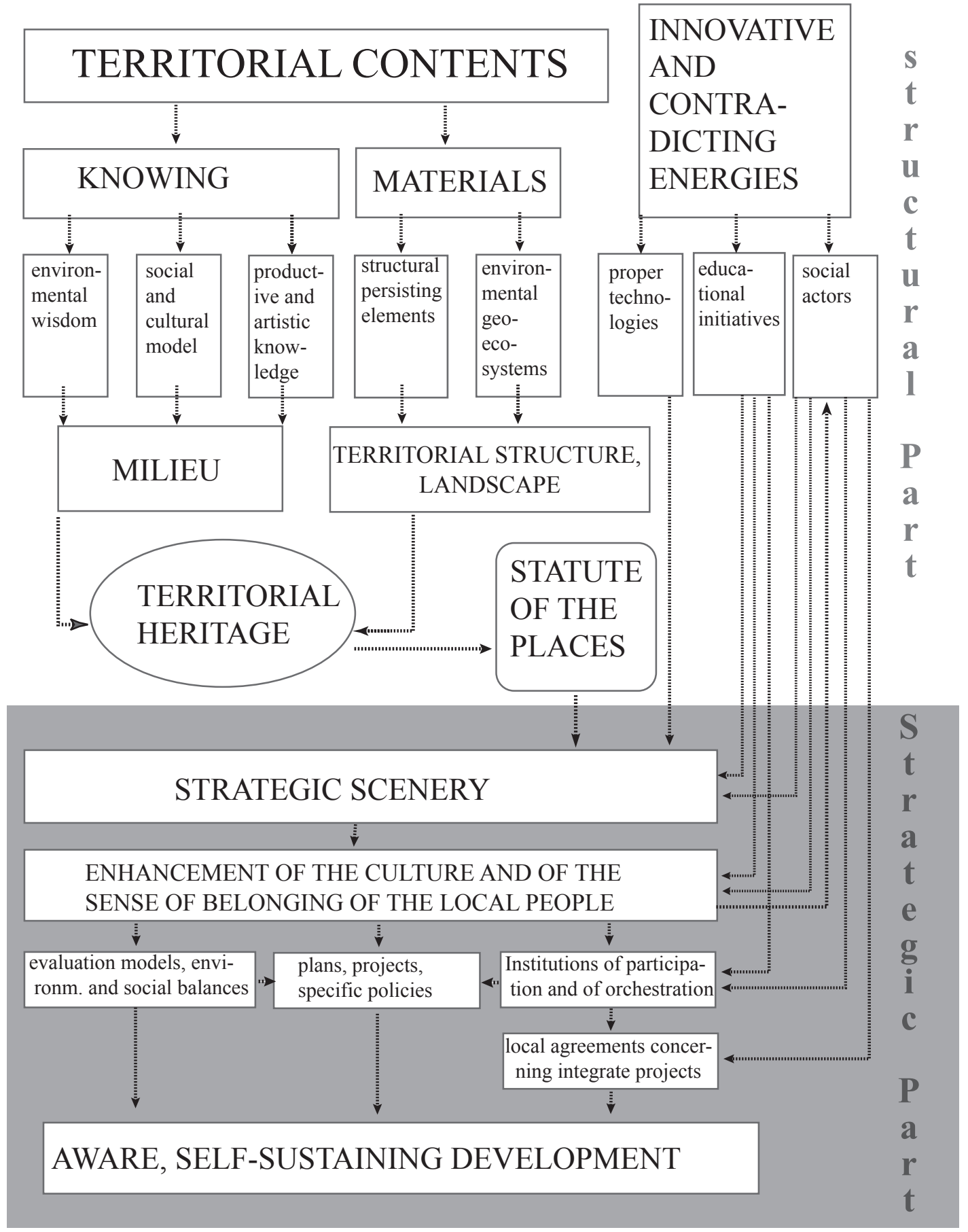

Fig. 5: Sketch of some of the possible components to be considered inside a strategy plan of sustainable local development. The sketch is derived with modifications from Magnaghi (2006).

mechanisms, which tend to amplify in time and to determine favourable economic and political backgrounds to their continuation.

It must be said that something has changed in the culture of the people in the last years and that it is possible to recognize some signs of hope. So, many local and regional administrations have realized the importance of the big karst aquifers as strategic water resources. The karst aquifer of the Sette Comuni Plateau only would be able to furnish something like 300 millions of cubic meters of relatively good water (except for the organic pollution) in a year, about $70 \mathrm{~m}^{3} /$ for each inhabitant of the Veneto Region. While in the past nearly all the liquid wastes were dispersed in the environment, systems of 
sewer have been built or are under construction to convey the waters to treatment plants or outside of the karst areas. In general, public opinion is now more sensible to the environmental problems.

In any case, to engage battles against the sprawl of new buildings, the quarrying activities, the construction of new roads and factories could have the opposite effect of the one intended. It is like to become others Don Quijote de la Mancha fighting against the windmills.

On the contrary, it is certainly possible to apply to promote new trends and development styles like to favour the restoration of the old settlements and the requalification of the recent ones instead of the building of completely new structures; or to encourage forms of low impact tourism as the hiking, the cycling, the camping, the agri-tourism, promoting in the meantime the natural and cultural heritage of the areas and the quality of the local products, as the cheese, the agri-biological products, the craftsmanship, etc.

If both the local inhabitants and the tourists will be able to get a good knowledge of the mountain area and will learn to establish a profound relation with this, it will become easier both to stimulate projects respectful of the local heritage and to prevent intervention negative for the environment.

It is important to emphasize that the problem to individuate and to choose new more compatible directions for the development is for a large part a cultural problem and it may not be solved without a cultural revolution.
This revolution needs investment of time by persons well trained in the environmental, historical and geographical research. It is necessary to start learning experiences in the field involving both young and old people (like pensioners). Local people must be helped to understand the karst geo-ecosystem, the natural realm, the landscape, the local history, the cultural heritage (Castiglioni \& Sauro, 2002; Magnaghi, 2006). Local people have to develop a strong sense of belonging to their own geographical units. Especially, local people have to become and to feel protagonists, responsible of their own development.

Unfortunately the process of education needs time, while the changes resulting from the human activities are now impressively fast. Some experiences made in the last years are certainly positive (I remember here in particular the experience of the $3 \mathrm{KCl}$-Project, run inside the Program of the European Union - Culture 2000; see Castiglioni, 2005), but they are not enough. Especially, in the more important areas for the environmental and cultural heritage (natural parks, karst areas, etc.) it is necessary to start with initiatives of permanent education. These have to be carried on especially in the field, through the discovery of the local history, seen also as succession of episodes of human impact and interrelations between the natural and the human processes. In this strategic scenery it is fundamental to improve cooperation between different structures, as political authorities, research and educational organisations, local associations, etc.

\section{REFERENCES}

Avesani, B., G. Chelidonio, U. Sauro \& F. Zanini, 1986: "Terre rosse" in Lessinia: appunti sui significati geologici, preistorici e sugli usi tradizionali.- La Lessinia - ieri oggi domani, 83-102, Verona.

Bondesan, A. \& M. Meneghel, 1990: Impact by limestone exploitation in western Lessini Mountains (NorthEastern Italy).- Proc. Int. Conf. on Anthropogenic and environmental changes in karst, Czechoslovakia-Hungheria. Studia Carsologica 2, GGU, CSAV, 7-18.

Castiglioni, B. (Ed.), 2005: Paesaggi carsici - Architettura di una relazione unica tra uomo e ambiente: Montello.- Museo di Storia Naturale e Archeologia di Montebelluna.
Castiglioni, B. \& U. Sauro, 2002: Paesaggi e geosistemi carsici: proposte metodologiche per una didattica dell'ambiente.- In: Varotto M. \& Zunica M. (a cura di) - Scritti in ricordo di Giovanna Brunetta. Dipartimento di Geografia "G. Morandini", Università di Padova, 51-67.

Gams I., J. Nicod \& U. Sauro, 1993: Environmental changes and human impact in the Mediterranean Karst of France, Italy and Dinaric Region.- Catena suppl. 25, 59-98.

Magnaghi, A., 2006: Gli atlanti del patrimonio e la "statuto dei luoghi" per uno sviluppo locale autosostenibile.- In Bertoncin, M. \& Pase, A, (eds): Il territorio non è un asino - voci di attori deboli. Scienze Geografiche- Franco Angeli, Milano, 23-51.

Mietto, P. \& U. Sauro, 2000: Le Grotte del Veneto: pae- 
saggi carsici e grotte del Veneto. Regione del Veneto.- La Grafica Editrice (Vago di Lavagno, Verona), seconda edizione, $480 \mathrm{pp}$.

Sauro, U., 1977: Aspects de la morphogenèse anthropique dans le milieu karstique Alti Lessini.- Norois 95 (bis), 149-163.

Sauro, U., 1987: The impact of man in the karstic environments of the Venetian Prealps.- Karst and Man, University of Ljubljana. Study Group on Man's impact in Karst. Proc. Int. Symposium on Human Influence on Karst, Postojna, Yugoslavia, 1987, 241254.

Sauro, U., 1993: Human impact on the karst of the Venetian Fore-Alps (Southern Alps, Northern Italy).Environmental Geology 21/3, 115-121.

Sauro, U. [Scientific coordinator], 1994: Map of the human impact in the karst environment of the central-western Lessini Mountains.- In L. Sorbini, Ed. 1994: Geologia, idrogeologia e qualità dei principali acquiferi veronesi." Mem. Museo St. Nat. Verona, s.2/4.
Sauro, U., 1999a: Analisi e modellizzazione dei geo-ecosistemi carsici: verso un approccio globale per la comprensione della dinamica e della vulnerabilità degli acquiferi carsici.- Quaderni di Geologia Applicata, suppl. 2, 99, I/235-2

Sauro, U., 1999b: Towards a preliminary model of a Karst Geo-Ecosystem: the example of the Venetian ForeAlps. Karst 99, Etudes de géographie physique, suppl. n. 28, CAGEP, Université de Provence, 165-170.

Sauro, U., 2003: Asiago Plateau, Italy.- In J. Gunn (ed.) "Encyclopedia of Caves and Karst Science", 116-119. Fritzroy Dearborn, New York.

Sauro, U., A. Bondesan \& M. Meneghel (eds.), 1991: Proceedings of the International Conference on Environmental Changes in Karst Areas.- Quaderni del Dipartimento di Geografia 13, Università di Padova.

Sauro, U. \& M. Lanzingher, 1995: The study of the morphokarstic unit of Sette Comuni Plateau (Venetian Fore-Alps): State-of-the-art.- Studi Tridentini di Scienze Naturali - Acta Geologica, v. 70. 
